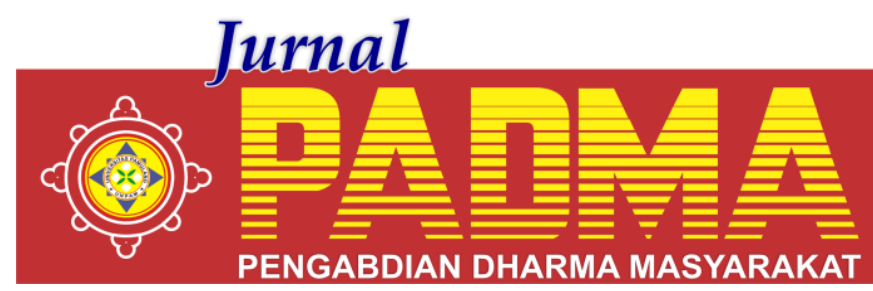

VOLUME 1, NOMOR 2, APRIL 2021

\title{
PENERAPAN STRATEGI DIGITAL MARKETING UNTUK MENINGKATKAN TINGKAT PARTISIPASI CALON PESERTA DIDIK DI SEKOLAH MENENGAH PERTAMA ISLAM TERPADU NURUL AMAL ISLAMIC BOARDING SCHOOL KOTA TANGERANG SELATAN
}

\author{
${ }^{1 *}$ Yayan Sudaryana , ${ }^{2}$ Juhaeri, ${ }^{3}$ Anteng Gustiana Dewi, ${ }^{4}$ Maretno Sibarani, \\ ${ }^{5}$ Muhammad Mudzakir, ${ }^{6}$ Fauzan Rahman Ismail, ${ }^{7}$ Deni Romasturia \\ Universitas Pamulang, Tangerang Selatan, Banten, Indonesia \\ *yayansudaryana@yahoo.com
}

\begin{abstract}
Abstrak
Pengabdian ini berjudul Penerapan Strategi Digital Marketing untuk meningkatkan Tingkat Partisipasi Calon Peserta Didik Di Sekolah Menengah Pertama Islam Terpadu Nurul Amal Islamic Boarding School Kota Tangerang Selatan. Tujuan umum dari kegiatan pengabdian kepada masyarakat ini adalah Memberikan pelatihan dan pengetahuan secara praktis ilmu manajemen dalam penerapan strategi digital marketing dalam rangka meningkatkan jumlah partisipan calon peserta didik baru setiap tahunnya. Metode yang digunakan adalah metode survey dan penyampaian materi secara langsung dan diskusi mengenai manajemen pemasaran, peraturan-peraturan yang menyangkut penggunaan media sosial seperti UU ITE, UU perlindungan konsumen, UU perdagangan dan strategi digital marketing untuk meningkatkan tingkat partisipasi calon peserta didik baru. Kesimpulan dari pengabdian kepada masyakat ini adalah bahwa pelatihan penerapan strategi digital marketing yang mencakup pengertian, macam, manfaat dan kekurangan digital marketing, aturan undang-undang yang berkaitan dengan aktifitas tersebut, serta materi tentang mengidentifikasi sasaran konsumen/pasar, mampu memaksimalkan aktifitas pemasaran dengan strategi digital marketing sehingga meningkatkan jumlah partisipan calon peserta didik baru di SMPIT Nurul Amal Islamic Boarding School Kelurahan Pondok cabe Ilir, Kecamatan pamulang, Kota Tangerang selatan.
\end{abstract}

Kata Kunci: Penerapan, Digital Marketing, Guru Nurul Amal Islamic Boarding School.

\section{Abstract}

This devotion is titled Implementation of Digital Marketing Strategy to Increase the Participation Rate of Prospective Students in Integrated Islamic Junior High School Nurul Amal Islamic Boarding School, South Tangerang City. The General purpose of this community. The general purpose of this community service activity is to provide training and knowledge in practical management science in the application of digital marketing strategies in order to increase the number of participants of prospective new students every year. The methods used are ddirect survey and material delivery methods and discussions on marketing management, regulation related to the use of social media such as the UU ITE, consumer protection laws, trade laws, and digital marketing strategies to increase the participantion rate of prospective new learners. The conclusion of this community service is that training on the implementation of digital marketing strategies that include understanding, sorts, benefits and disadvantages of digital marketing, the rule of law related to these activities, as well as material about identifying the target consumer/market, able to maximize marketing activities with digital marketing strategies so as to increase the number of participants of prospective new students in SMPIT Nurul Amal Islamic Boarding School at Pondok Cabe Ilir Village, Pamulang District, South Tangerang City.

Keywords: Application, Digital Marketing, Teacher at Nurul Amal Islamic Boarding School.

\section{PENDAHULUAN}

Kepala dinas pendidikan dan kebudayaan kota Tangerang Selatan, Taryono mengakui jumlah sekolah tinggi tingkat SMP Negeri tidak sepadan dengan tingkat SMP berstatus Swasta. Pasalnya, Disdikbud kota Tangsel memiliki catatan ketimpangan fasilitas pendidikan berstatus negeri itu dari data keseluruhan sekolah tingkat SMP yang ada di kota Tangsel. Sekolah SMP di Tangsel yang berstatus negeri sebanyak 22 sekolah. Sedikitnya sekolah negeri yang tersedia di kota Tangsel menambah panjang daftar minimnya fasilitas 
pendidikan yang dikelola oleh pemerintah kota Tangsel. Bahkan tak jarang orang tua calon siswa harus rela menyekolahkan anaknya ke sekolah berstatus swasta. Banyaknya jumlah SMP swasta di Tangerang Selatan dan sedikitnya jumlah SMP negeri ditangerang selatan seharusnya menjadi angin segar bagi sekolah menengah pertama SMPIT Nurul Amal Islamic Boarding School merupakan sekolah swasta yang berada dibawah naungan Yayasan Pendidikan Islam Nurul Amal yang berdiri di tahun 2020 berdasarkan akta notaris No.7/02/04/1997. Berdirinya SMPIT Nurul Amal Islamic Boarding School untuk memenuhi kebutuhan masyarakat yang akan melanjutkan sekolahnya ke tingkat SMP. Yayasan Pendidikan Islam Nurul Amal ini memiliki sekolah yang bersifat boarding school yaitu berbentuk asrama sebagai tempat tinggal siswanya dan memeiliki fasilitas pendidikan yang sudah sesuai standar mulai dari ruang kelas, perpustakan, laboratorium, beserta tenaga pendidik yang berkompeten dibidangnya masing - masing, sehingga SMPIT Nurul Amal mampu bersaing dengan sekolah SMP lainnya yang ada di Tangerang Selatan.

Diera industri 4.0 dimana ilmu pengetahuan menjadi dasar utama untuk menjalankan suatu usaha yang mudah dilakukan untuk memperkenalkan SMPIT Nurul Amal Islamic Boarding School melalui jaringan internet yang dalam waktu singkat dapat disebarkan. Digital marketing merupakan salah satu strategi alternatif untuk menyampaikan informasi mengenai SMPIT Nurul Amal Islamic Boarding School. Digital marketing merupakan kegiatan marketing termasuk branding yang menggunakan berbagai media berbasis web seperti blog, website, email, adwords, ataupun jejaring sosial (ridwaan sanjaya \& josua tarigan, 2009:47). Digital marketing merupakan suatu usaha untuk mempromosikan sebuah brand atau produk dengan menggunakan media digital atau internet yang dapat menjangkau konsumen secara tepat waktu, relevan dan pribadi. Menurut Ridwan Sanjaya \& Joshua Tarigan (2009) digital marketing adalah kegiatan pemasaran termasuk branding yang menggunakan media, seperti blog, website, e - mail, dan berbagai macam jaringan media sosial. Dalam bukunya, (David Evans dan Jake McKee, 2010) mengatakan bahwa social media marketing di praktekkan untuk melibatkan pelanggan pada lokasi social online dimana para pelanggan secara alami menghabiskan waktu. Menurut Santoso (2017) pemasaran sosial media merupakan bentuk pemasaran yang dipakai untuk menciptakan kesadaran, pengakuan, ingatan dan bahkan tindakan terhadap suatu merek, produk, bisnis, individu, atau kelompok baik secara langsung maupun tidak langsung dengan menggunakan alat dari web sosial seperti blogging, microblogging, dan jejaring sosial.

Dengan adanya sosial media marketing memudahkan para pelaku usaha untuk berinteraksi dengan calon konsumen atau customer-nya melalui daring atau online. Biaya yang dikeluarkan tidak terlalu besar dan tidak ada batasan waktu selama tersambung dengan internet. Media sosial berperan saat pemasaran kegiatan perusahaan membentuk hubungan individu dengan pelanggan dan memberi perusahaan peluang untuk mengakses pelanggan (Kelly et al., 2010).

Menurut Mangold dan Faulds (2009), tindakan pemasaran melalui media sosial (social media marketing) adalah bagian dari promotional mix dalam komunikasi merek. Penelitian Bruhn et al. (2012) mengungkapkan bahwa komunikasi media sosial memiliki dampak yang signifikan terhadap ekuitas merek. Kaitannya dalam membangun merek, khususnya lembaga sekolah, informasi mengenai instansi dan karakteristik pelayanan pendidikan yang disampaikan kepada customer harus jujur dan sesuai dengan realita yang ada.

Penggunaan digital marketing memang sangat menguntungkan, yaitu dapat menekan biaya pemasaran sedangkan dampak dan manfaat yang diberikan sangat luas dimana bisa menjamah pangsa pasar yang tak tersekat oleh jarak. Hal ini sesuai dengan asas dan tujuan dalam pemanfaatan Teknologi dan transaksi elektronik pada UU ITE tahun 2018 pasal 4 ayat b.

Menurut UU Perdagangan no. 7 tahun 2014 pasal 65 ayat 1, setiap pelaku usaha yang memperdagangkan barang dan/atau jasa dengan menggunakan sistem elektronik wajib menyediakan data dan/atau informasi 
secara lengkap dan benar. Kemudian UU perdagangan no 7 tahun 2014 pasal 65 ayat 3 yang berbunyi, penggunaan sistem elektronik sebagaimana dimaksud pada ayat 1 wajib memenuhi ketentuan yang diatur dalam undang-undang informasi dan transaksi elektronik atau UU ITE. UU ITE sendiri pada pasal 28 tahun 2018 berbunyi; Setiap Orang dengan sengaja dan tanpa hak menyebarkan berita bohong dan menyesatkan yang mengakibatkan kerugian konsumen dalam Transaksi Elektronik akan dipidana dengan pidana penjara paling lama 6 (enam) tahun dan/atau denda paling banyak Rp1.000.000.000,00 (satu miliar rupiah) sesuai UU ITE tahun 2018 pasal 45 ayat 2 .

Menurut penelitian yang dilakukan oleh Hidayah, IN (2020), menyebutkan bahwa responden menyatakan sebanyak 74\% iklan yang dilakukan oleh CV Ratatia Rumbai Indonesia dengan digital marketing menarik konsumen. Hal ini berkaitan dengan penerapan Digital Marketing sebagai Strategi Pemasaran pada usaha CV.Ratatia Indonesia Rumbai yaitu: Website yang terjamin asli dan berizin, iklan yang tidak ada unsur gharar, adanya kerjasama atau kemitraan dan hubungan yang baik antara penjual dan konsumen sesuai dengan tinjauan Islam. Hal ini juga sejalan dengan penelitian yang dilakukan oleh Hidayah, N (2018) tentang efektifitas dan efisiensi pemasaran dengan digital marketing, yaitu. Living Space dan Efo Store memasarkan produknya secara online dengan melakukan optimalisasi digital marketing tools secara terintegrasi. Berdasarkan penjelasan diatas, dapat diketahui bahwa digital marketing sangat diperlukan untuk mempromosikan atau memperkenalkan/ mengiklankan sekolah tersebut sehingga informasi lebih cepat untuk disebarkan dan tidak membutuhkan waktu serta biaya yang banyak. Namun demikian, pengkajian untuk mewujudkan strategi digital marketing di SMPIT Nurul Amal Islamic Boarding School belum dilakukan di Yayasan tersebut. Dengan demikian perlu dikaji kembali dalam penerapan strategi digital marketing lebih mendalam mengenai aspek-aspek yang perlu diterapkan untuk memperkenalkan sekolah tersebut sehingga dapat meningkatkan peserta didiknya.

\section{METODE}

Metode pelaksanaan kegiatan ditunjukkan dengan gambar 1. Sebagai langkah awal dengan dilakukannya kegiatan pengumpulan informasi untuk mengetahui kondisi lokasi, permasalahan dan kebutuhan riil dari instansi tempat dilakukannya PKM ini. Selanjutnya tim akan melakukan pengabdian dengan memberikan edukasi tujuan dari kegiatan ini yaitu memberikan pengetahuan tentang pentingnya peranan digital marketing dalam rangka meningkatkan jumlah partisipasi peserta didik baru, serta memberikan edukasi tentang memaksimalkan pemanfaatan digital marketing disertai dengan pemahaman peraturan perundang-undangan.

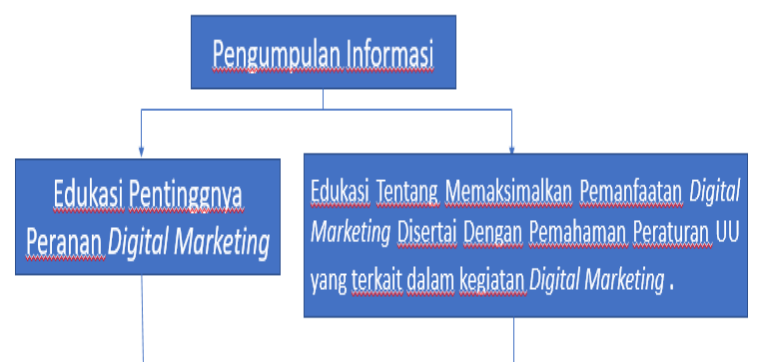

Implikasi Penerapan Strategi Digital Marketing pada Peningkatan Tingkat Partisipasi Calon Peserta Didik Baru

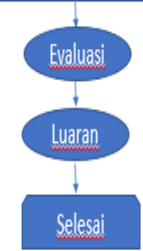

Gambar 1. Kerangka Metode Pelaksanaan

Rencana yang dilakukan untuk kegiatan ini:

1. Tahap persiapan, Persiapan ini difokuskan dengan menyiapkan semua peralatan yang dibutuhkan untuk melaksanan kegiatan ini, studi literatur dan melakukan koordinasi dengan pihak sekolah untuk melakukan kegiatan sosialisasi penerapan digital marketing dalam rangka meningkatkan tingkat partisipasi peserta ddik

2. Penentuan Lokasi, Pada tahap ini dilakukan kunjungan ke lokasi untuk menentukan tempat (lokasi) pelatihan penerapan digital marketing dalam rangka meningkatkan tingkat partisipasi peserta didik. 
3. Kegiatan sosialisasi berupa materi digital marketing beserta aturan dan UndangUndang yang berkaitan dengan penerapan digital marketing

\section{HASIL DAN PEMBAHASAN}

Tahap Pengumpulan Data dan

Pendahuluan Pengabdian

1. Identifikasi Sasaran

Identifikasi dilakukan oleh tim untuk menentukan objek atau peserta yang akan menerima sosialisasi serta jenis kontribusi macam apa yang dibutuhkan sehingga menghasilkan manfaat dan keuntungan bagi kemajuan instansi. Peserta dari kegiatan pengabdian ini adalah Kepala sekolah SMPIT Nurul Amal Islamic Boarding School, staf dan jajarannya beserta anggota Yayasan Pendidikan Islam Nurul Amal sebagai pemangku kepentingan.

2. Perencanaan Kegiatan Pelatihan

Setelah tim melakukan diskusi, untuk selanjutnya tim melakukan perencanaan kegiatan pelatihan diantaranya :

Pendampingan

terhadap

manajemen dalam pengembangan digital marketing sebagai upaya meningkatkan pemasaran yang dilakukan sekolah.

Sosialisasi UU ITE diantaranya: pencemaran nama baik dan hoax atau berita bohong. dan Sosialisasi tentang UU perdagangan. Materi ini berisi tentang pihak mana saja yang terlibat dalam suatu bisnis, dan bagaimana hukum perdagangan mempengaruhi industri jasa khususnya di bidang pendidikan.

Ulasan mengenai Undang-undang Perlindungan Konsumen dan Peraturan Menteri Perdagangan mengenai kegiatan pengiklanan dalam kaitannnya dengan digital marketing yang akan diterapkan di SMPIT Nurul Amal Islamic Boarding School.

Sosialisasi tentang model marketing dalam mengidentifikasi dan mengenal target konsumen danMemaksimalkan pemanfaatan digital marketing dengan memperbaiki website resmi sekolah dan penggunaan media sosial lainnya secara maksimal seperti facebook, Instagram, tiktok, twitter dan youtube.
Pelaksanaan pelatihan dan penyampaian materi diisi oleh Dr. Yayan Sudaryana, M.M. dan Muhammad Mudzakir, S.E dari kalangan mahasiswa Universitas Pamulang sebagai narasumber. Teori berlangsung selama 2 jam.

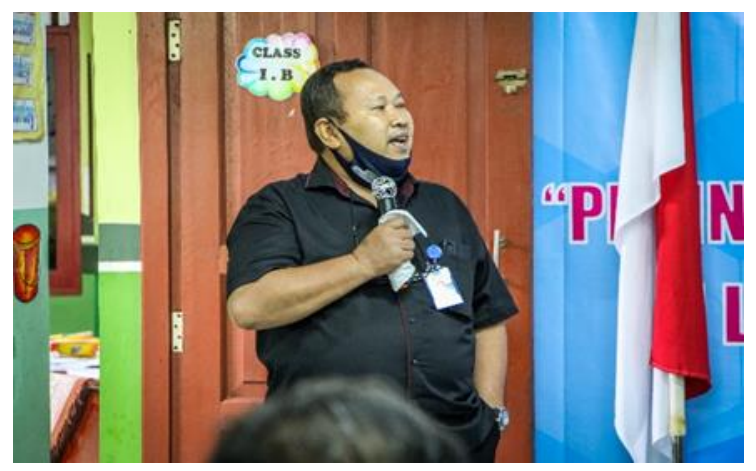

Gambar 2. Penyampaian materi oleh pembicara Dr. Yayan Sudaryana, M.M

Kemudian diakhiri dengan diskusi dan tanya jawab berlangsung hangat dan aktif ditandai dengan banyaknya pertanyaan yang diajukan oleh sasaran peserta pengabdian.

3. Evaluasi Program

Tahap evaluasi merupakan penilaian setelah rangkaian kegiatan dilakukan. Evaluasi ini dengan menggunakan kuesioner yang disebar melalui google form setelah pelatihan dilakukan kepada para peserta pengabdian, untuk dilakukan evaluasi apakah pelatihan ini memberikan dampak ilmu pengetahuan berupa pemahaman terhadap peran digital marketing dalam meningkatkan jumlah peserta didik baru.

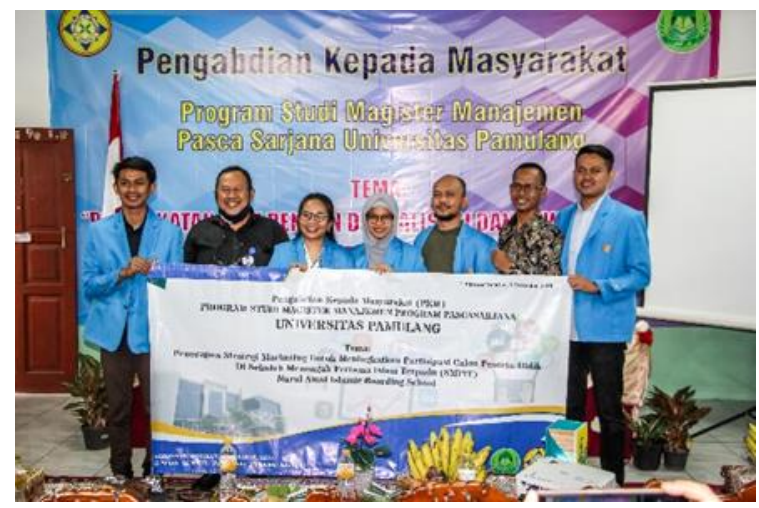

Gambar 3. Tim Pengabdian Kepada Masyarakat 


\section{PENUTUP}

Dari kegiatan pengabdian kepada masyarakat ini dapat disimpulkan bahwa pelatihan penerapan strategi digital marketing yang mencakup pengertian, macam, manfaat dan kekurangan digital marketing, aturan undang-undang yang berkaitan dengan aktifitas tersebut, serta materi tentang mengidentifikasi sasaran konsumen/pasar, mampu memaksimalkan aktifitas pemasaran dengan strategi digital marketing sehingga meningkatkan jumlah partisipan calon peserta didik baru di SMPIT Nurul Amal Islamic Boarding School Kelurahan Pondok cabe Ilir, Kecamatan pamulang, Kota Tangerang selatan.

\section{DAFTAR PUSTAKA}

Evans, Dave and jake Mckee. (2010). Sosial Media Marketing, Indianapolis. Wiley Publising, Inc.

Bruner, Gordon. (2009). Marketing scales handbook. Carbondale: USA.

Erlangga, H. (2020). The Challenges of Organizational Communication in the Digital Era. Solid State Technology, 63(4), 1240-1246.

Hidayah, Nurul (2018). Analisis Strategi Digital Marketing Dalam Membantu Penjualan Living Space Dan Efo Store. Skripsi; Universitas Islam Indonesia.

Hidayah, NI (2020). Penerapan Digital Marketing Sebagai Strategi Pemasaran Pada Usaha CV. Ratatia Indonesia Rumbai Ditinjau Menurut Ekonomi Islam. Skripsi: Universitas Islam Negeri Sultan Syarif Kasim Riau.

Kelly, et all (2010). Avoidance of advertising in social networking sites: The teenage perspective. Journal of Interactive Advertising, 10(2), 16-27.

Kotler, Philip and Kevin Lane Keller. (2016). Marketing Management, 15th Edition, Pearson Education,Inc.

Mangold, W. G., \& Faulds, D. J. (2009). Social media: The new hybrid element of the promotion mix. Business Horizons, 52, 357-365.

Sanjaya, Ridwan dan Josua Tarigan. (2009). Creative Digital Marketing.PT Elex Media Komputindo. Jakarta.

Santoto. (2017). Pengaruh Promosi Penjualan Dan Inovasi Produk Terhadap Keputusan Pembelian Dan
Dampaknya Terhadap Loyalitas Pelanggan. Jurnal Administrasi dan Bisnis Vol 11, No. 1, 2017.

Jumlah Data Satuan Pendidikan (Sekolah) Per Kabupaten/Kota : Kota Tangerang Selatan. (18 November 2020). Diakses melalui

https://referensi.data.kemdikbud.go.id /index.

Pelayananpublik.id (2019, 05 Agustus) Pengertian Yayasan, Tujuan, Syarat, dan Cara Mendirikannya. (16 November 2020). Diakses melalui https://pelayananpublik.id/2019/08/ $05 /$ pengertian-yayasan-tujuan-syaratdan-cara-mendirikannya/.

Pengertian, Kelebihan, jenis, dan Strategi Digital Marketing. (07 Januari 2021) Diakses melalui .https://www.jurnal.id/id/blog/meng enal-digital-marketing-konsep-danpenerapannya/.

Pengertian Digital Marketing. (07 Januari 2021). Diakses melalui https://www.dosenpendidikan.co.id/d igital-marketing-adalah/.

Wartakota.tribunnews.com (2020, 25 Juni) Jumlah SMP Negeri Kota Tangsel Tak Mencukupi, Disdikbud Kota Tangsel Enggan Bangun Sekolah Baru. (16 November 2021) Diakses melalui https://wartakota.tribunnews.com/20 20/06/25/jumlah-smp-negeri-kotatangsel-tak-mencukupi-disdikbudkota-tangsel-enggan-bangun-sekolahbaru.

Dua Puluh Tiga Ribu Lulusan SD Tangsel Berebut 7.000 Kursi SMP Negeri. (18 November 2020). Diakses melalui https://nusantara.medcom.id/jawabarat/peristiwa-jabar/eN4RvE3k-23ribu-lulusan-sd-tangsel-berebut-7000-kursi-smp-negeri.

UU no. 7 tahun 2014 tentang Perdagangan.

UU No. 8 Tahun 1999 tentang Perlindungan Konsumen

UU No.11 Tahun 2008 tentang Informasi dan Transaksi Elektronik (ITE)sebagaimana telah diubah oleh UU No. 19 Tahun 2016 tentang Perubahan atasUU No. 11 Tahun 2008 tentang Informasi dan Transaksi Elektronik (ITE). 